\title{
PANCASILA SEBAGAI DASAR FALSAFAH PAJAK DI INDONESIA
}

\author{
Oleh: Thomas Abbon \\ thomas.abbon@gmail.com \\ Universitas Kristen Indonesia, Jakarta, Indonesia
}

\begin{abstract}
It has become a national consensus that the Pancasila is the basic philosophy of the state and nation of Indonesia, which underlies all actions and deeds in the life of the state and society. Through TAP MPRS No. XX / MPRS / 1966 it has been established that Pancasila is the source of all sources of law in Indonesia. The consequence is that any existing laws and regulations must be based and must not con ict with Pancasila, including taxation.
\end{abstract}

Keywords: national consensus; Pancasila; tax; laws and regulations.

\section{PENDAHULIAAN}

Negara Republik Indonesia sebagai suatu negara hukum modern (welfare state), mempunyai tujuan sebagaimana ditetapkan dan digariskan dalam Pembukaan UUD 1945, yaitu :

1. Melindungi segenap bangsa Indoneisa dan seluruh tumpah darah Indonesia,

2. Memajukan kesejahteraan umum,

3. Mencerdaskan kehidupan bangsa,

4. Ikut melaksanakan ketertiban dunia berdasarkan kemerdekaan, perdamaian abadi dan keadilan sosial $^{1}$

Tujuan tersebut dicapai melalui serangkaian program-program pembangunan yang dilaksanakan secara berkesinambungan melalui tahapan pembangunan nasional. Dalam rangka pelaksanaan pembangunan nasional untuk mencapai tujuan negara sebagaimana dikemukakan diatas, negara memerlukan sejumlah dana guna membiayai pelaksanaan pembangunan nasional, baik untuk pengeluaran rutin maupun untuk pengeluaran pembangunan.

Untuk membiayai pengeluaran permerintah sebagaimana dikemukakan diatas, dalam struktur

1 Oleh Garis-Garis Besar Haluan Negara dirumuskan sebagai menciptakan masyarakat adil dan makmur, merata material dan spiritual berdasarkan Pancasila dan UUD 1945
Anggaran Pendapatan dan Belanja Negara telah ditetapkan sejumlah pos penerimaan negara, seperti tabungan, pinjaman, sumber gas dan minyak bumi, pajak dan sebagainya. Dalam beberapa periode belakangan ini, melalui APBN dapat dilihat bahwa pajak merupakan sumber penerimaan negara yang terutama yang menduduki peranan strategis dalam membiayai pengeluaran pernerintah, setelah menurunnya persentase penerimaan negara dari sumber gas dan minyak bumi. Kenyataan menunjukkan bahwa sekalipun negara maju tidak dapat melepaskan diri dari pajak sebagai sumber penerimaan negara, Pajak merupakan suatu "conditio sine quanon" bagi penambahan keuangan negara. Bedasarkan apa yang diuraikan di atas, teryatalah bahwa pajak merupakan iuran yang ditarik dari masyarakat dan kemudian dikembalikan lagi kepada masyarakat dalam bentuk pelayanan umum (publik service). Pajak mempunyai tujuan untuk mensejahterakan rakyat.

Disisi lain dapat dikemukakan bahwa pajak merupakan suatu beban. Rochmat Sumitro, mengemukakan bahwa pungutan pajak mengurangi penghasilan/kekayaan individu, tetapi sebaliknya merupakan penghasilan masyarakat yang kemudian dikembalikan lagi kepada masyarakat melalui pengeluaran-pengeluaran rutin pembangunan yang 
akhimya kembali lagi kepada seluruh masyarakat yang bermanfaat bagi rakyat (tidak hanya yang menbayar pajak, tetapi juga kepada rakyat yang tidak membayar pajak) ${ }^{2}$

Selanjutnya dikemukakan bahwa dari segi ekonomi, pajak adalah peralihan kekayaan dari sektor swasta ke sektor publik berdasarkan undang-undang yang dapat dipaksakan dengan tidak mendapat imbalan (tegen presentasfy) yang secara langsung dapat ditujukan, yang digunakan untuk membiayai pengeluaran umum dan yang digunakan sebagai alat pendorong, penghambat atau pencegah untuk mencapai tujuan yang ada di luar bidang keuangan negara $\left.{ }^{3}\right)$.

Santoso Brotodihardjo, 4), mengemukakan bahwa dari segi ekonomi mikro, pajak dilihat dalam hubungannya dengan pemenuhan kebutuhan setiap individu. Pajak dilihat sebagai sesuatu yang mengurangi income seseorang tanpa mendapat imbalan, sehingga pajak dianggap sebagai beban yang memberatkan, mengurangi pendapatan seseorang, mengurangi daya beli dan akhimya akan mempengaruhi kesejahteraannya. Dengan mernperhatikan kedua aspek diatas, yaitu disatu pihak merupakan beban setiap individu dan di lain pihak bertujuan untuk kesejahteraan rakyat banyak, maka dalam pelaksanaannya dicarikan dasar falsafahuntuk pemungutan pajak. Dasar falsafah pemungutan pajak pada tingkatnya akan ditindak lanjuti dengan dasar hukum pemungutan pajak.

\section{PEMBAHASAN}

\section{Pancasila Sebagai Falsafah Pemungutan Pajak}

Sebagaimana dikemukakan diatas, bahwa Pancasila adalah merupakan pandangan hidup bangsa Indonesia. Pancasila merupakan dasar falsafah negara, sehingga merupakan landasan ideal dalam segala tidakan dan perbuatan baik dalam hidup bermasyarakat rnaupun dalam hidup bemegara. Demikian juga dalam lapangan perpajakan. Pancasila merupakan dasar falsafah pemungutan pajak. Pancasila dengan kelima silanya harus mendapat tempat dan dijabarkan dalam setiap peraturan perundang-undangan perpajakan.

\footnotetext{
2 Rochmat Sumitro, Prof. DR. SH, Pengantar Singkat Hukum Pajak, FT. Eresco Bandung, 1987. hal. 2
}

Peraturan perundang-undangan perpajakan. Peraturan perundang-undangan perpajakan merupakan ceminan dari Pancasila dengan kelima silanya.

Melalui TAP MPRS No.XX/MPRS/1966 telah ditetapkan bahwa Pancasila merupakan sumber dari segala sumber hukum di Indonesia. Oleh karena itulah setiap peratura perundang-undangan, termasuk bidang pajak harus bersumber dari Pancasila dan tidak boleh bertentangan dengan kelima sila Pancasila.

Dibawah ini akan diuraikan hubungan kelima sila Pancasila dengan pemungutan pajak di Indonesia, kemudian dikaitkan dengan peraturan perundangundangan didang perpajakan.

1. Sila Pertama, Ketuhanan Yang Maha Esa

Salah satu butir pengalaman sila pertama Pancasila adalah percaya dan taqwa kepada Tuhan Yang Maha Esa sesuai dengan agama dan kepercayaan masing-masing atas dasar kemanusiaan yang adil dan beradap. Dalam kaitannya dengan pemungutan pajak, bahwa setiap agama-agama surgawi mengajarkan kewajiban umatNya untuk taat kepada perintah negara, termasuk memberikan apa yang menjadi kewajibannya kepada negara dan masyarakat, disamping kewajibannya kepada Tuhan. Dalam hubungannya dengan peraturan perundang-undangan bidang perpajakan secara tegas dlsebutkan melalui UU No. 6 tahun 1983 jo UU Xo. 9 tahun 1994 jo UU No. 16 tahun 2000 tentang Ketentuan Umum dan Tata Cara Perpajakan (KUP) yang menentukan bahwa pajak merupakan kewajiban kenegaraan dan dimaksudkan sebagai pelaksanaan pembangunan nasional.

2. Sila Kedua, Kemanusiaan Yang Adil dan Beradab

Persamaan derajat, persamaan hak dan persamaan kewajiban antara sesama manusia, merupakan salah satu wujud pengalaman sila kedua Pancasila. Sikap yang demikian juga dianut dalam pemungutan pajak yang melarang adanya diskriminasi di kalangan wajib pajak, Butir lain ialah "mengembangkan rasa tenggang rasa". Dalam lapangan perpajakan, hal ini diwujudkan rnelalui adanya toleransi atau tenggang rasa dari aparat yang berweiiang membentuk peraturan perundang-undangan, mulai dari tingkatrancangannya hingga penyusunannya, 
Rasa tenggang rasa, khususnya dimaksud dalam menentukan tarif dan persentase pajak yang dikenakan. Wujud pengamalan sila kedua yang lain adalah tidak semena-mena terhadap orang lain. Dalam hubungannya dengan pemungutan pajak, para fiskus diwajibkan untuk memberikan pelayanan yang baik dan terhormat bagi para wajib pajak. Sesuai dengan ketentuan undang-undang ditetapkan bahwa apabila wajib pajak merasa keberatan atas tindakan fiskus dalam menetapkan pajak terhutang, undang-undang memberikan sarana bagi pengajuan "keberatan" maupun banding dan gugatan kepada Badan Penyelesaian Sengketa pajak yang dibentuk beidasarkan UU No. 17 tahun 1997 tentang Badan Pernyelesian Sengketa Pajak (BPSP).

\section{Ketiga, Persatuan Indonesia}

Wujud pengamalan sila ketiga Pancasila antara lain adalah rela berkorban demi kepentingan bangsa dan negara serta menepatkan kepentingan bangsa dan negara diatas kepentingan pribadi atau golongan. Dalam kaitannya dengan peraturan perundang-undangan perpajakan., hal ini dapat dilihat dalam ketentuan tentang KUP yang menentukan bahwa kewajiban perpajakan merupakan kewajiban beregaraan dan sebagai bentuk partisipasi aktif seluruh rakyat dalam membiayai pembangunan nasional. Pemungutan pajakmerupakan penerapan kewenangan publik yang dimiliki oleh pemerintah untuk rnencapai tujuannya. Tercermin bahwa dengan pernbayaran pajak, setiap watga negara telah mengorbankan sebagian harta kekayaan demi untuk kepentingan umum, yaitu kesejahteraan rakyat banyak. Dengan pajak, berarti seseorang telah menempatkan kepentingan umum diatas kepentingan pribadi atau golongan.

4. Sila Keempat, Kerakyatan Yang Dipimpin Oleh Hikmat Kebijaksanaan Dalam Permusyawaratan/ Perwakilan.

Perwujudan sila keempat dari Pancasila terda- pat dalam pasal 23 ayat (2) UUD 1945, yang menentukan bahwa pemungutan pajak harus ditetapkan dengan undang-undang. Bahwa pajak yang ditarik dari masyarakat, haruslah terlebih dahulu dimusyawarahkan dengan rakyat untuk selanjutnya diambil mufakat dengan kewajiban untuk menerima hasil mufakat dengan rasa tanggung jawab serta melaksanakannya dengan baik. Mekanisme pengarnbilan keputusan politik dalam bentuk perundang-undangan sepenuhnya mencerminkan wujud pengamalan sila keempat Pancasila, Dalam proses lahirnya suatu undang-undang perpajakan, merupakan cerminan dari pelaksanaan asas demokrasi dalam pemungutan pajak,

5. Sila Kelima, Keadilan Sosial Bagi Seluruh Rakyat Indonesia

Asas Keadilan dalam hukum pajak tercermin dalam ketentuan bahwa tidak semua warga negara sebagai wajib pajak, Undang-undang perpajakan yang berlaku menentukan kriteria untuk adanya seorang menjadi wajib pajak, walaupun setiap orang merupakan subyek pajak. Demikian juga halnya bahwa terhadap wajib pajak dengan penghasilan yang sama tidak berarti dikenakan tarif pajak yang sama.

Perwujudan asas keadilan dalam pemungutan pajak dilakukan melalui penyempurnaan undangundang perpajakan. Penjelasan Umum UU No. 17 tahun 2000 tentang Pajak Penghasilan ditetapkan bahwa salah satu tujuan penyempurnaan undangundang tersebut adalah untuk lebih meningkatkan keadilan pengenaan pajak.

Wujud asas keadilan dalam pemungutan pajak juga ternyata dari tujuan pajak itu sendiri yang ditujukan untuk kepentingan umum, tidak pemah membedakan individu yang membayar pajak maupun yang tidak membayar pajak. Dalam peraturan perundangundangan perpajakan dap at dilihat adanya ketentuan umum yang berfungsi sebagai tafsiran autentik. Demikian juga disediakannya saran bagi wajib pajak untuk memperoleh keadilan sebagai akibat tindakan dan perbuatan aparat perpajakan.

Secara khusus dapat dilihat UUPPH yang menentukan tarif progresif, sebagaimana diatur dalam pasal 17 UU No. 17 tahun 2000, yaitu : 
Wajib Pajak Orang Pribadi Dalam Negeri

\begin{tabular}{|l|l|}
\hline Lapisan Penghasilan Kena Pajak & Tarif \\
\hline s/d Rp. 25 juta & $05 \%$ \\
Rp. 25 juta s/d Rp. 50 juta & $10 \%$ \\
Rp. 50 juta s/d Rp. 100 juta & $15 \%$ \\
Rp. 100 juta s/d Rp. 200 juta & $25 \%$ \\
Lebih dari Rp. 200 juta & $35 \%$ \\
s/d Rp. 25 juta & $10 \%$ \\
\hline
\end{tabular}

Wajib Pajak Badan Dalam Negeri

\begin{tabular}{|l|l|}
\hline Lapisan Penghasilan Kena Pajak & Tarif \\
\hline s/d Rp. 50 juta & $10 \%$ \\
Rp. 50 juta s/d Rp. 100 juta & $15 \%$ \\
Lebih dari Rp. 100 juta & $30 \%$ \\
\hline
\end{tabular}

\section{Dasar Hukum Pemnngutan Pajak}

Dasar konstitusional dari pemungutan pajak di Indonesia dapat dilihat dalam pasal 23 ayat

(2) UUD 1945 yang menetukan bahwa segala pajak untuk keperluan negara berdasarkan undang-undang. Penjelasannya mengemukakan bahwa oleh karena penetapan belanja mengenai hak rakyat untuk menentukan nasibnya sendiri, maka segala tindakan yang menetapkan beban kepada rakyat seperti pajak dan lain-lainya harus ditetapkan dengan undang-undang, yaitu dengan persetujuan Dewan Perwakilan Rakyat.

Dari apa yang ditentukan dalam pasal tersebut, tidak ada pajak dalam bentuk dan jenis apapun yang ditetapkan dalam bentuk Kepres, Keputusan Menteri Keuangan, dan lain-lain, di luar dari bentuk undang-undang, kecuali itu dimaksudkan sebagai aturan pelaksanaan atau aturan organik. Permasalahannya adalah mengapa harus dengan undang-undang.

Pemungutan pajak dengan undang-undang merupakan salah satu ciri dan unsur pajak.
Pemungutan pajak dengan undang-undang sudah merupakan asas universal dalam abad modern ini. Dengan perkataan lain bahwa setiap penarikan pajak yang dilakukan dengan tidak berdasarkan ketentuan undang-undang adalah tindakan yang inskonstitusional. " No taxation without representation". Taxation without Representation is robbery".

Oleh Rochmat Sumitro ${ }^{6}$ ), permasalahan sebagaimana dimaksud di atas jangan dijawab, karena pasal 23 (2) UUD 1945 sudah menetukan demikian. Pasal 23 ayat (2) memang benar merupakan sumber formal dari hukum pajak, tetapi sebenamya dalam ketentuan itu tersirat falsafah pajak yang lebih modern. Dengan memperhatikan eksistensi dan keberadaan pajak, ditambah dengan pendekatan pajak dari segi ekonomi mikro, maka yang terjadi adalah pengurangan kekayaan seseorang atau badan hukum/badan usaha tanpa adanya imbalan atau kontra pesiasi yang secara langsung. Sehingga dengan demikian, yang terjadi adalah peralihan 
hak-hak dasar manusia. Peralihan hak-hak dasar seorarng individu tanpa adanya suatu imbalan adalah termasuk jenis kejahatan, yaitu tindak pidana pencurian, perampasan, perampokan dan sebagainya, kecuali adalah pemberi sukarela. Pajak bukanlah bermaksud demikian, oleh karenanya harus dengan persetujuan Dewan Perwakilan Rakyat sebagai wakil rakyat. Dan apabila sudah mendapat persetujuan DPR, berarti sudah mendapat persetujuan dari rakyat.

Di sisi lain dapat dikemukakan bahwa pengenaan pajak yang ditetapkan dengan undang- undang merupakan wujud pelaksanaan asas demokrasi dalam perpajakan, sekaligus merupakan perwujudan asas konsensualisme dalam perpajakan, hanya saja dalam perwujudannya terjadi secara sistem perwakilan, Dengan itu, maka pemungutan pajak oleh negara terhadap masyarakatnya adalah berdasarkan persetujuannya sendiri, yang diberikan melalui wakilnya yang duduk di lembaga perwakilan rakyat,

\section{KESIMPULAN DAN SARAN}

Pancasila sebagai pandangan hidup (weltanschaung) bangsa dan negara Indonesia merupakan dasar falsafah negara yang mendasari setiap tindakan dan perbuatan dalam kehidupan kenegaraan dan kemasyarakatan. Hal ini sudah disepakati secara konstitusional melalui TAP MPRS No. XX/MPRS/1966 yang menetapkan bahwa Pancasila merupakan sumber dari segala sumber hukum di Indonesia. Dalam kaitannya dengan peraturan perundang-undangan bidang perpajakan, tampaknya kelima sila dari Pancasila sudah diterapkan dan dijabarkan sedemikian rupa sebagaimana diuraikan dalam pembahasan di atas.

Dasar konstitusional pemungutan pajak di Indonesia ditemukan dalam pasal 23 ayat

(2) UUD 1945, yang sudah merupakan asas universal dalam pemungutan pajak dewasa ini. Dengan pengaturan yang demikian, ternyatalah bahwa dalam pemungutan pajak di Indonesia telah menerapkan asas demokrasi dan asas konsensualisme.

\section{Daftar Pustaka}

Brotodihardjo R. Santoso, SH. 1986. Pengantar Ilmu Hukum Pajak. Bandung. PT. Eresco Bandung.

Pringgodigdo, H.A.K, Drs. SH. 1966. Tiga Undang Undang Dasar. Jakarta. PT. Pembangunan.

Sumitro Rochmat, Prof. DR. SH. 1987. Pengantar Singkat Hukum Pajak. Bandung. PT. Eresco ,1998. Asas Dan Dasar Perpajakan 1. Band- ung. PT Eresco.

Lima Undang Undang Perpajakan Tahun 1997. Ja- karta. CV. Novindo Pustaka Mandiri.

Lima UU RI Bidang Perpajakan Tahun 2000. Jakarta.

CV Mini Jaya Abad 
